\title{
The Effect of Political Connections on Corporate Environmental Social Responsibility: Large Sample Evidence from China
}

\author{
Wenlong Wang, Zhanming Jin, Jiao Jie \\ Department of Innovation, Entrepreneurship and Strategy, \\ Tsinghua University, \\ Beijing, China
}

\begin{abstract}
This study investigates the relationship between firms' political connections and corporate environmental social responsibility (CESR). Results indicate: (1) Private corporations are more likely to engage in CESR if their leaders are members of the "Two Meetings." (2) Private corporations with greater financial resources are more likely to engage in actions related to CESR and financial resources provide firms with access to political connections. (3) Private corporations whose leaders take government position as officials tend to participate in more substantial activities related to CESR instead of adopting decoupling strategy when engaging in CESR activity. The basic motivation for corporations to voluntarily engage in environmental protection is to achieve political legitimacy. The result provides the environmental policymakers a useful way to encourage CESR.
\end{abstract}

Keywords-corporate environmental social responsibility; political connection; political legitimacy

\section{INTRODUCTION}

From 1978, China has seen rapid economic development and the average growth rate of GDP reached $9.8 \%$ per year. However, serious environmental problems also arise in the past 30 years. As one development report from World Bank indicated, 6 out of 10 most polluted cities in the world are in China [1]. The air and the water have been polluted, increasing health hazard in the population. According to China's State Environmental Protection Administration (SEPA), the damage to the environment cost of China equals $10 \%$ of its gross domestic product (GDP) annually [2]. With the deteriorating of the environment, environmental problems have become major constraints for China's sustainable development in the future.

Since pollution-intensive production constitutes a critical source of environmental pollution, firms' action on environmental protection may greatly impact a country's total environment. As a kind of market failure, environmental pollution produced by the firm needs to be regulated by the government. However, corporations' voluntary bearing on environmental protection is more important. After all, only firms volunteer to engage in environmental protection, can the serious environmental problem be resolved once and for all.

This paper focuses on firms' action on voluntary environmental protection, that is, corporate environmental social responsibility. One possible important predictor of
CESR in China is firms' political connections [3]. In organizational theory, corporate political connections can be an important source of political legitimacy, which reduces the uncertainty in the transitional society like China. Since government control strategic resources that shape firms' competitive environment and positions, corporations are impending to gain political legitimacy [4]. Using a set of survey data, we examine whether firms' needs for political legitimacy can be a source of CESR.

\section{HYPOTHESIS DEVELOPMENT}

Government inspection and regulation consist of an important source of uncertainty for corporations and have become to greatly impact firms' strategies and operations in China [5]. To survive, firms develop political connections to decrease uncertainty and increase access, information, legitimacy, and resources. Therefore, a corporation's political connections can be a kind of strategic assets. In China, it's not hard to see that a corporation's leader has political connections. In addition to a member of the Chinese communist Party, these leaders often take positions in China's political system. For example, firms' leaders can join state's political councils such as the National People's Congress (NPC) or the Chinese People's Political Consultative Conference (CPPCC). These two meetings are collectively called "Two Meetings," constituting an important source of firms' political legitimacy. When it comes to corporate environmental social responsibility, we believe that firms' leaders on these councils are more likely to lead to corporations responding to public requirement for engaging in CESR to keep their reputations. To sustain the political legitimacy from the government, firms often take action, for example, engaging in CESR, in accordance with the public's expectations. This is especially important for private firms since there are few public ways they can show commitment to the government guide. According to the discussion above, we put forward the following hypothesis.

H1: Private corporations are more likely to engage in CESR if their leaders are members of the "Two Meetings."

Previous studies have shown that corporations with more financial resources are more likely to participate in political activities and that organizational slacks greatly influence CESR. Research has also indicated that corporations with greater financial resources are more able to follow legitimated actions. As have been discussed above, since CESR is to gain legitimacy from the 
government, corporations with greater slack resources and higher-performing firms are more likely to operate these resources to engage in CESR [6]. For those in private sectors, which cannot easily benefit from government support as state-owned enterprise does, financial resources are more related to CESR. In addition, more financial resources may also produce stronger external pressure for these corporations to be more public and engage in more CESR-related actions. Following the discussion above, we put forward the following hypothesis.

H2: Private corporations with greater financial resources are more likely to engage in CESR-related actions.

A corporation's CESR-related reaction to government guide depends on the strength of government scrutiny on its behavior. A usual reaction is decoupling, the symbolic compliance to the public or government demand with few substantive changes [7]. As a useful strategy for corporations, decoupling "enables organizations to maintain standardized, legitimating, formal structures, while their activities vary in response to practical considerations." However, the adoption of decoupling strategy by a firm is not without costs. In fact, those decoupling firms face risks. That is, since a corporation's information disclosure is sometimes exposed to the government and the public, if the firm is found to adopt obfuscation or symbolic CESR compliance instead of having done what it reported, the public and the government will punish the firm. Decoupling risks varies across firms, depending on their characteristics. Firms under government high-level scrutiny tend to face more decoupling risks [8]. Therefore, these firms tend to engage in more substantial CESR activities. In China, leaders in corporations can take government positions, such as Chairman of Local People's Congress or Chairman of the CPPCC. Such bureaucratic embeddedness provides firms with greater access to resources and benefits. However, bureaucratic embeddedness also make corporations suffer stronger government scrutiny, increasing the risk of decoupling [9]. Once a firm is found to treat the government and the public, its legitimacy will be seriously deteriorated. To sustain its political legitimacy, these firms tend to conduct more substantial CESR-related activities. Following the reasoning above, we put forward the following hypothesis.

H3: Private corporations whose leaders take government position as officials tend to participate in more substantial CESR-related activities instead of adopting decoupling CESR strategy.

\section{RESEARCH DESIGN}

\section{A. Variables}

\section{1) Corporate environmental social responsibility} (CESR)

The main focus of this study is the predictors that would affect CESR and its substance. Accordingly, we have two dependent variables. Dummy variable CESR1 is assigned as "1" for those firms who join environmental groups, otherwise, CESR1 is assigned as " 0 ." CESR substance, coded as CESR2, is measured by the amount of corporate environmental donations. Since environmental donation requires firms to invest substantive resources, we use it as a measure to reflect firms' substance in CESR. To compare, we divide the amount of environmental donation by total revenue for each firm.

2) Political connection (PC)

As discussed above, there are two types of political connections. To analyze CESR, we use the information whether a corporation's leader joins NPC or CPPCC as a measure for political connections. The variable, PC1, is divided into two categories: " 1 " is assigned to those firms whose leaders are membership of the NPC or CPPCC; " 0 " is assigned to those firms whose leaders are not membership of the NPC or CPPCC. To analyze the substance of CESR, we use the information whether a corporation's leader is government official as measure for political connections, which is named as PC2. It equals 1 when corporations' leaders has been an officer the central or regional governments, and it is 0 otherwise.

3) Financial resources

We measure firms' financial resources using two variables, ROA and slack resources (SR). ROA is the return of assets calculated as the ratio of net income to total assets, which is regarded as the best performance measure in China [10]. Slack resources are the sum of cash flow of a firm, reflecting the available resources firms can operate to engage in various activities. To eliminate size effect, we divide slack resources by total assets for each firm.

\section{4) Firm size (SZ)}

This study uses fixed asset amount (SZ1), the number of employees (SZ2), and sales revenue (SZ3) as proxies for business size, all of which are the natural logarithm forms measured at the end of the year.

5) Business condition (BC)

We control for asset-liability ratio to measure firms' business conditions because a firm with high debts may have difficulty in financing. The lack of ability in financing may hinder CESR.

6) Sector (SE)

We control for sectors in which firms belong to since the product type may influence firms' CESR-related activity. It equals 1 when corporations engage in manufacturing, and it is 0 otherwise.

7) Firm age (FA)

We control for firm age, which is measured as the number of years since the firm was established. 
TABLE I. OLS AND LOGIT ANALYSIS ON CESR.

\begin{tabular}{|c|c|c|c|}
\hline Variable & Model 1 & Model 2 & Model 3 \\
\hline SZ1 & $0.72^{* * *}(0.25)$ & $0.83^{* * *}(0.25)$ & $0.60^{*}(0.25)$ \\
\hline SZ2 & $0.11^{* * * *}(0.02)$ & $0.11^{* * * *}(0.02)$ & $0.06^{*}(0.02)$ \\
\hline SZ3 & $0.17^{*}(0.27)$ & $0.82^{* *}(0.27)$ & $0.38(0.29)$ \\
\hline PC1 & $1.64^{* * * *}(0.25)$ & $1.57^{* * * *}(0.25)$ & \\
\hline PC2 & & & $3.37^{* * * * *}(0.24)$ \\
\hline ROA & $0.67^{*}(0.30)$ & $1.8^{* * *}(0.61)$ & $0.83^{* *}(0.26)$ \\
\hline SR & $3.13^{* * * *}(0.24)$ & $3.34^{* * * *}(0.24)$ & $3.45^{* * *}(0.24)$ \\
\hline $\mathrm{BC}$ & $1.72^{* * * *}(0.249)$ & $1.57^{* * * *}(0.26)$ & $1.61^{* * *}(0.25)$ \\
\hline SE & $0.40(0.265)$ & $0.34(0.29)$ & $0.56(1.57)$ \\
\hline FA & $0.74^{*}(0.37)$ & $0.92^{*}(0.37)$ & $0.92^{* * * *}(0.09)$ \\
\hline $\mathrm{R}^{2}$ & 0.17 & 0.20 & \\
\hline Likelihood ratio & & & -216.18 \\
\hline
\end{tabular}

\section{B. Sample selection and data}

The sample of this study comes from the survey of "the private enterprise research group." This survey was conducted in 2010 and 2012. According to the enterprise's size and sector in China's Statistical Yearbook, the survey sampled 9236 private enterprises. The data contain firms' identification information and their operation and performance information extracted from balance sheets and income statements. These firms cover 31 provinces and municipalities in China and contain private enterprises of various sizes and types. Therefore, the sample has high representativeness. Since we focus on the effect of political connections on CESR, we delete those firms with missing information on political connections. At last, we achieve 8623 samples.

\section{RESULTS}

We conduct logit regression and OLS regression to test our hypothesis. For $\mathrm{H} 1$ and $\mathrm{H} 2$, since the dependent variable CESR1, is a dummy variable, indicating whether a firm engaging in CESR or not, we apply the logit regression technique. For $\mathrm{H} 3$, since the dependent variable, CESR2, is a continuous variable, indicating the substance of CESR, we apply the OLS technique. The results are shown in Table I.

Model 1 presents the result for the influence of PC1 on CESR. As predicted by H1, the estimated coefficient for PC1 is positively significant at the level of $1 \%$. The result means that private corporation's leaders joining NPC or CPPCC indeed have influence on firms' actions and private firms whose leaders have joined the NPC or CPPCC are more likely to engage in CESR to sustain their reputation and political legitimacy.

Model 2 presents the result for the influence of financial resources on CESR. As predicted by H2, the estimated coefficients of ROA and SR are positively significant at the level of $1 \%$. The result indicates that sufficient financial resources are necessary conditions for private firms' operations of sustaining political legitimacy. This result is especially reasonable for private firms since they have no easy access to resources supported by the state. Without financial resources, it's hard to gain political legitimacy for private firms.
Model 3 presents the result for the influence of PC2 on CESR. As predicted by $\mathrm{H} 3$, the estimated coefficient of PC2 is positively significant at the level of $1 \%$. The result finds that taking official position in the government for private corporations' leaders expose their firms under strong government scrutiny. In this situation, decoupling action for a firm is risky. Considering more access to resources provided by the government official position, firms' leaders tend to invest more substantive resources in CESR-related activities for the sustaining of their political legitimacy.

\section{CONCLUSIONS}

This study examines whether political legitimacy can be a motivation for corporate environmental social responsibility. Using a large set of survey data, we test the political legitimacy in the organizational theory under Chinese context. Results show that private corporations are more likely to engage in CESR if their leaders are members of the "Two Meetings"; Private corporations with greater financial resources are more likely to engage in actions related to CESR and financial resources provide firms with access to political connections; Private corporations whose leaders take government position as officials tend to participate in more substantial activities related to CESR instead of adopting decoupling strategy when engaging in CESR activity. The underlining mechanism under these results is corporations' needs to achieve political legitimacy. In addition, the result we find is beneficial for China's environmental policymakers to encourage CESR.

\section{ACKNOWLEDGMENTS}

The research work was supported by National Natural Science Foundation of China under Grant No. 71172003.

\section{REFERENCES}

[1] The World Bank, Cost of pollution in China, 2007.

[2] E. Economy, K. Lieberthal, Scorched earth: Will environmental risks in China overwhelm its opportunities? Harvard Business Review, (June), pp. 88-96, 2007.

[3] S. Sharma, H. Vredenburg, Proactive corporate environmental strategy and the development of competitively valuable organizational capabilities. Strategic Management Journal, 19, pp. 729-753, 1998.

[4] D.A. Schuler, K. Rehbein, The filtering role of the firm in corporate political involvement. Business \& Society, 36(2), pp. 116-139, 1997.

[5] A.J. Hillman, Politicians on the board of directors: Do connections affect the bottom line? Journal of Management, 31(3), pp. 464-481, 2005.

[6] A.J. Hillman, G.D. Keim, D. Schuler, Corporate political activity: A review and research agenda. Journal of Management, 30(6), pp. 837-857, 2004.

[7] J.W. Meyer, B. Rowan, Institutionalized organizations: Formal structure as myth and ceremony. American Journal of Sociology, 83(2), pp. 340-363, 1977.

[8] B.J. Dickson, Red Capitalists in China: The Party, Private Entrepreneurs, and Prospects for Political Change. Cambridge University Press, Cambridge, UK, 2003. 
[9] J.P.H. Fan, T.J. Wong, T. Zhang, Politically connected CEOs, corporate governance, and post-IPO performance of China's newly partially privatized firms. Journal of Financial Economics, 84(2), pp. 330-357, 2007.
[10] M.W. Peng, Y. Luo, Managerial ties and firm performance in a transition economy: The nature of a micro-macro link. Academy of Management, 43(3), pp. 486-501, 2000. 